\title{
STOCK "BROKERS" AS AGENTS AND DEALERS
}

\section{WILLIAM O. DOUGLAS $\dagger$ AND GEORGE E. BATES $\dagger \dagger$}

The blurred fashion in which courts have at times treated the distinctions between stock "brokers" acting on the one hand as agents or on the other as dealers has resulted in several paradoxical situations. One of these is illustrated by the procedural and substantive law aspects of Howell, McArthur \& Wiggin, Inc. v. Weinberg. ${ }^{1}$

Plaintiff, a stock "broker," sued to recover the price of 25 shares of United Founders Corporation common stock alleged to have been purchased by it "as broker" for and on account of defendants. By a general denial and motion to dismiss, defendants raised the point that no "agency" existed on the part of the plaintiff to purchase for and on account of defendants but that the transaction constituted a sale to defendants by plaintiff as agent for the seller. That issue was submitted to the jury which returned a verdict for plaintiff for the price asked less the commission which the seller allowed plaintiff. The judgment entered on the verdict was affirmed by the Appellate Division. The issue before the Court of Appeals was stated as follows: "The sole question of law for the consideration of this court is whether this judgment, unanimously affirmed, is supported by any evidence from which the inference can be drawn that plaintiff acted as agent for defendants." 2 That court, after concluding that the evidence supported the verdict, affirmed the judgment.

From the record it appears that Founders General Corporation was distributing stock of its affiliate, United Founders, and had made arrangements with various dealers, including plaintiff, to sell and distribute these shares under an agreement whereby plaintiff was enabled to obtain the shares at a price less than the quotation to the customer. The existence of this arrangement and its details were not controverted nor denied but were unequivocally established by plaintiff's own witness. ${ }^{3} \mathrm{~A}$ re-

†Sterling Professor of Law, Yale University.

†tAssistant Professor, Graduate School of Business Administration, Harvard University; Research Associate on the Sterling Foundation, Yale School of Law.

For a more extended discussion of the security business see the authors' Secondary $D$ istribution of Securities-Problems Suggested by Kinney v. Glenny (1932) 41 YaLE L. J. 949.

1. 260 N. Y. 250,183 N. E. 379 (1932).

2. Id. at $252,183 \mathrm{~N}$. E. at 379 .

3. Record, 48, 53. Plaintiff's witness, Walter S. Wiggin, Cross.

Q. Your business was the general buying and selling and dealing in stocks and securities generally; is that a fact? A. Yes.

Q. And not being a member of any of the stock exchanges you were not bound by 
view of the facts clearly established at the trial indicates that by all known standards and criteria of the security business ${ }^{4}$ plaintiff would be classified as a dealer. (1) Plaintiff was the local sales representative of what amounted to a wholesaling house. This was established by its admission at the trial, ${ }^{5}$ its local advertising, ${ }^{6}$ and by the fact that it placed itself in a class with such well-known security merchants as Harris, Forbes \& Company and Bond \& Goodwin. ${ }^{7}$ (2) It sold to defendants at as nearly a fixed price as would be possible in such sales of stock. ${ }^{8}$ (3) It confirmed the purchase to defendants as "sold to you" rather than as "bought for your account." 9 (4) It ordered the stock from the wholesaler without receiving an advance payment or a "margin" from the customer. $^{10}$ (5) It solicited the order for this particular stock, ${ }^{11}$ thus indicating it was endeavoring to sell this security, not just soliciting brokerage business. (6) By its own admission it was bound by the prices and rules of the wholesaling house..$^{12}$ (7) It charged its customer no commission. ${ }^{13}$ (8) It made no disclosure to the customer of its profit in the transaction. ${ }^{14}$ (9) It received a dealer's discount from the whole-

their rules, particularly with relation to the commissions you could charge; isn't that a fact? A. No, we were not bound by the same rules. We were bound by some rules.

Q. Who formulated or promulgated the rules that you were bound by? A. The Founders General Corporation.

Q. You were their agents and distributors in this section? A. We were one of the agents and distributors. Harris, Forbes \& Company, Bond \& Goodwin and others were operating under the same agreement that we were.

Q. What was your connection with the United Founders Corporation? A. We were the distributing, buying and selling organization for all securities of the American Founders group in which United Founders was included. . . .

Q. So that you were buying that stock at $725 \% \mathrm{~s}$ and purporting to represent customers under a buying order to whom you were charging $\$ 74$ ? A. Yes, sir.

Q. You charged no commission to the customer whom you claim you were representing in this case, did you? A. None whatever.

Q. And your profit was represented by the difference in the price that you paid for these securities and the amount that you received from your customers generally? A. Yes, sir. ...

4. The matter is fully discussed in Bates and Douglas, Secondary Distribution of Securities-Problens Suggested by Kinney v. Glenny (1932) 41 Yare L. J. 949, 951-953, 980-985.

5. Note 3, supra.

6. Note 17, infra.

7. Note 3, supra.

8. Ibid.

9. The confirmation read:

We are pleased to confirm sale to you of: 25 shs. United Founders Corp. Common $74 \quad 1850$

Plaintiffs' Exhibit 12, Record, 136.

10. Record, 65, 66, 83 .

11. Note 18 , infra.

12. Note 3, supra.

13. Ibid.

14. Record, 59. See note 54, infra. 
saling house. ${ }^{15}$ (10) It did not call for payment until delivery of the stock was tendered. ${ }^{16}$

Furthermore, there was no evidence whatsoever that defendant thought plaintiff was acting as agent rather than as dealer. Plaintiff had advertised locally that it was acting as distributor for Founders General Corporation, ${ }^{17}$ and, according to defendants, they knew at the time the order was placed that plaintiff was seeking to distribute an allotment of United Founders shares. ${ }^{18}$ It is therefore surprising both to find the trial court

15. Note 3, supra.

16. Record, $68,69,87,88$. The fact that plaintiff did not carry an inventory would not itself make him out to be a dealer. As is pointed out hereafter that fact alone is consistent with either an agent or a dealer relationship.

17. Record, 27. Plaintiff's witness, Ernest E. Kellogg, Cross.

Q. Did you ever see any of the advertising your firm did in the papers about that time? A. I don't remember any specifically.

Q. Will you deny they advertised they were the general representatives and distributors of the American Founders group, including the United Founders stock in this section? A. That is a fact.

18. Record, 81, 82, 89, 90. Defendant's witness, Maurice Weinberg, Direct.

Q. Just tell us what you remember he [plaintiff's salesman, Kellogg] said to you at that time. A. He came into my store and said he had an allotment of some United Founders and wanted to sell me some. ...

Q. What else did he say? A. He suggested that I had some International securities and some other stock that he had sold me, and suggested that I sell them and buy United Founders from him....

Q. What, if anything, did he say about the price of the United Founders? A. Well, it was selling at $74 \mathrm{I} / 2$ and he said he could sell to me at 74 that day.

Q. What did you say? A. I told him if he could dispose, sell my other stocks I would buy the 25 shares of the United Founders from him.

Q. What did you next hear regarding the situation? A. I got a confirmation that they had sold me 25 shares of United Founders.

\section{Cross}

Q. But you knew that confirmation which they sent you ... meant that they were telling you that they had purchased for your account 25 shares of United Founders? A. Did not.

Q. You didn't know that is what it meant? A. No, sir; it didn't mean that.

Q. What did it mean to you? A. It meant they had sold me 25 shares of United Founders.

The version given by plaintiff's witness, Ernest E. Kellogg, was:

\section{Direct}

Q. What did you say to them [Weinbergs] and what did be say to you? . . A. I suggested that they sell the odd lot of preferred stocks or odd lot securities that they had in this particular group and invest it in the United Founders. . . .

Q. What did Maurice [Weinberg] say to you when you suggested that? A. He asked me the price of the United Founders at that time.

Q. What did you tell him? A. I said it was selling around 74. . .

Q. What did he say? A. He said to me "Sell the odd lot securities and buv 25 shares of United Founders."

Q. Wasn't it a fact that you said that your firm ... had an allotment or a position 
submitting the case to the jury and the appellate courts affirming the judgment entered on the verdict.

\section{II}

It is no surprise, however, that counsel for a dealer would first endeavor to establish his case on an agency theory. There are distinct procedural and substantive law advantages in being able to sue as agent rather than as dealer. In the first place, it has been quite uniformly held that shares of stock fall within the statute of frauds section of the Uniform Sales Act, ${ }^{10}$ being included in the words "goods or choses in action." 20 Consequently, where the "broker" acts as dealer, the transaction is a contract of sale within the statute, ${ }^{21}$ and enforceable only

in a block of United Founders and could sell it to him at 74, which would be about one-half a point under the ordinary market? A. No.

Q. Do you deny that you said anything of that kind? A. I do. I don't remember it.

Q. That is, you don't remember saying it? A. I don't remember saying anything of that kind. Record 23, 24, 26.

19. UntForar Sales Act $\$ 4$.

20. Mlinois-Indiana Fair Association v. Phillips, 328 Ill. 368, 159 N. E. 815 (1927); Guppy v. Moltrup, 281 Pa. 343, 126 Atl. 766 (1924); Davis Laundry \& Cleaning Co. v. Whitmore, 92 Ohio St. 44, 110 N. E. 518 (1915); De Nunzio v. De Nunzio, 90 Conn. 342, 97 Atl. 323 (1916).

21. F. C. Adams, Inc. v. Frank H. Thayer \& a. Ex'rs., 85 N. H. 177, 155 Atl. 687 (1931), af'd., 156 Atl. 697 (N. H. 1931); Farr v. Fratus, 277 Mass. 346, 178 N. E. 657 (1931); see Pascal v. Hess, 7 N. J. Misc. 884, 885, 147 Atl. 472, ibid. (Sup. Ct. 1929); and cf. Kellner v. Kener, 104 Misc. 254, 171 N. Y. Supp. 814 (Sup. Ct. 1918); Mattingly v. Pennie, 105 Cal. 514, 39 Pac. 200 (1895); Tompkins v. Sheehan, 158 N. Y. 617,53 N. E. 502 (1899).

The court in F. C. Adams, Inc. v. Frank H. Thayer \& a. Ex'rs., supra, said by way of dictum, at 182-183, 155 Atl. at 690-691:

"Unless specially agreed otherwise, the common understanding is that in the ordinary transaction a broker buying securities for a customer does not buy them as the latter's agent. The customer is not regarded as the broker's undisclosed principal who may be held by the seller to answer:for any liability of the broker in making the purchase. The eeller and the customer have no relations with each other, and the broker deals independently with each. Both the customer and the seller look only to the broker in their respective undertakings with him. While the seller expects that the broker is buying for a customer, he does not count on any liability of the customer as the broker's principal. This at least is believed to be the generally accepted view when the customer is undisclosed, although the seller knows or believes that the broker is buying for a customer. Special terms in the customer's engagement of the broker may alter the relationship. But, as the business of buying and selling securities is ordinarily conducted, the broker would seem to be an independent contractor rather than an agent. It is true that he renders $\mathfrak{a}$ service and carries out an order. But this is not the test. The broker is his own master in carrying out the order, and the customer has no control of its execution. Where control is not given, no agency is created.

"If it is not common knowledge that this is the view taken of such transactions in the business world, and if such view may seem a departure from the law as generally understood to prevail, yet the theory that the customer here was the undisclosed principal of 
when its requirements are satisfied. ${ }^{22}$ And, although a confirmation slip may be a sufficient memorandum of the contract to satisfy the statute, where the confirmation slip does not conform to the contract a court of equity has no power to reform it so as to make the contract enforceable. ${ }^{23}$ But where one acts as agent for the customer the statute of frauds provision of the Sales Act is inapplicable to the order given by the latter, ${ }^{24}$ since there was no sale from the agent to the customer.

Secondly, where the dealer is suing as vendor for damages or for the price of the securities he is confronted with the usual rules of the law of sales. In a majority of the few jurisdictions which have passed upon this point, stocks are held to come within the Sales Act, ${ }^{25}$ although "things in action" are excluded from the category of "goods." ${ }^{20}$ The measure of recovery against the vendee for refusal to accept delivery of the stock might not be the contract price but rather damages computed by the difference between the contract price and the market price at the time of delivery. ${ }^{27}$ In the absence of evidence of such difference the recovery would be limited to nominal damages. ${ }^{28}$ To recover the

the broker in the latter's purchases of the stock may not be upheld. The broker's purchases were at prices other than the customer's orders, and its contracts to buy were not the same as those of the customer to buy. The sellers might not claim a sale to the customer. No agency existed to charge the customer to meet the broker's obligations in its purchases. They were transactions independent of the customer's orders, although made in reliance upon the orders. They were the broker's own business. As one of the plaintiff's witnesses testified, the broker might dispose of his purchases as he saw fit until he applied them to the acceptance of the orders."

22. Cohen v. Paine, Webber \& Co., 113 Conn. 295, 155 Atl. 71 (1931) (part payment); Bibb v. Allen, 149 U. S. 481 (1893); Porter v. Wormser, 94 N. Y. 431, (1884) (bonds; ratification and failure to plead).

23. Freedman \& Co., Inc. v. Newman, 255 N. Y. 340, 174 N. E. 703 (1931).

24. Rogers v. Gould, 6 Hun. 229 (N. Y. 1875); Picard v. Beers, 195 Mass. 419, 81 N. E. 246 (1907); Sutro v. Jacobson, 96 N. J. L. 555, 115 Atl. 79 (1921); Rodman v. Weinberger, 81 N. J. L. 441 , 79 Atl. 338 (1911); Bibb v. Allen, supra note 22 ; Libaire v. Feinstein, 133 Misc. 27, 213 N. Y. Supp. 3 (N. Y. City Ct. 1928).

25. Wills v. Investors Bankstocks Corp., 257 N. Y. 451,178 N. E. 755 (1931) ; Postel v. Hagist, 251 Ill. App. 454 (1928); Orr v. Keith, 245 Mass. 35, 139 N. E. 508 (1923); Crichfield-Loeffler, Inc. v. Taverna, 4 N. J. Misc. 310, 132 Atl. 494 (Sup. Ct. 1926); Friedman v. Bachmann, 234 App. Div. 267, 254 N. Y. Supp. 689 (1st Dep't 1932) ; Corvin v. Grays Harbor Washingtonian, Inc., 151 Wash. 585, 276 Pac. 902 (1929); id., 159 Wash. 92, 292 Pac. 412 (1930). Contra: Henderson v. Plymouth Oil Co., 13 F. (2d) 932 (W. D. Pa. 1926); Millard v. Green, 94 Conn. 597, 110 Atl. 177 (1920); Smith v. Lingelbach, 177 Wis. 170,187 N. W. 1007 (1922) ; Morris F. Fox \& Co. v. Lisman, 208 Wis. 1, 240 N. W. 809 (1932) (bonds).

26. UnIFORM SALES ACT $\$ 76$ (1). And see the dissent of Crane, J., in Wills v. Investors Bankstocks Corp., supra note 25, at 458-59, 178 N. E. at 757: "The Personal Property Law applies to the buying and selling of commodities, things that can be manually delivered. Stock is a chose in action, a mere fractional interest in the capital of a corporation."

27. Crichfield-Loeffler, Inc. v. Taverna, supra note 25.

28. Ibid. 
contract price would require satisfaction of the conditions of Section 63 of the Sales Act, ${ }^{29}$ which restricts recovery to instances where the property in the stock had passed to the buyer, or where the price was payable on a day certain, irrespective of delivery or of transfer of title, or where the stock could not readily be resold for a reasonable price, though property.in the stock had not passed. ${ }^{30}$

If, however, the "broker" is acting as an agent of the customer, the problem of whether there is sufficient passing of the title to the shares to warrant a suit for the price arises in a somewhat different way. On acquisition of the shares by the agent the title is said to pass to the customer directly, the "broker" holding the shares as pledgee for the amount of his advances. ${ }^{31}$ The difference is marked in case of bankruptcy of the "broker." Where he was acting as dealer the customers are his general creditors for all advances made unless title "had passed to the buyers on proper allocation by the seller" to his contracts of sale. ${ }^{32}$ The mere fact that the dealer has such stock in his possession is not sufficient

29. Friedman v. Bachmann, supra note 25. And where the customer sues the dealer on the contract to sell, the ordinary rules as to damages or specific performance would be applicable. See UnIrorar SAIEs Acr $\S$ 66, 67, 68; Smurr v. Kaman, 301 III. 179, 133 N. E. 715 (1921) ("If the shares are readily obtainable in the open market specific performance will not be decreed, but if the shares have no market rating and cannot easily be obtained elsewhere, specific performance will be granted."); Morgan v. Bartlett, 75 W. Va. 293, 83 S. E. 1001 (1914). See cases collected in Note (1923) 22 A. L. R. 1032.

30. Corwin v. Grays Harbor Washingtonian, Inc., supra note 25; Agar v. Orda, 144 Misc. 149, 258 N. Y. Supp. 274 (Sup. Ct. 1932). When the Sales Act is held to be inapplicable to sales of stock, the rights of the parties would be determined in accordance with the general principles of law governing the performance of contracts. Thus it has been beld that where there has been no repudiation of the contract by the buyer prior to the time when plaintiff tendered the stock, the plaintiff, on tender and refusal of the buyer to accept and pay, has a choice (1) to hold the stock for the benefit of the buyer and sue for the price; (2) to elect to sell the stock and recover the difference between the selling price and the contract price; or (3) to keep the stock and recover the difference between the contract price and the market price at the time of the breach and at the time and place of delivery. Smith v. Lingelbach, supra note 25. Cf. Agar v. Orda, supra.

31. Ie Marchant v. Moore, 150 N. Y. 209, 44 N. E. 770 (1896) ; Markham v. Jaudon, 41 N. Y. 235 (1869); Skiff v. Stoddard, 63 Conn. 198, 26 Atl. 874 (1893); Richardson v. Shaw, 209 U. S. 365 (1908); Blankenhorn-Hunter-Dublin Co. v. Thayer, 199 Cal. 90, 247 Pac. 1088 (1926). For the contrary view in Massachusetts as respects marginal transactions, see Papadopulos v. Bright, 264 Mass. 42, 47, 161 N. E. 799, 801 (1928); Crehan v. Megargel, 235 Mass. 279, 126 N. E. 477 (1920); Mexar, The LAw of Stockbrokers aNd Stock Exchanges (1931) \& 41. On outright purchases by the customer through the "broker" as agent the stock becomes the property of the customer when acquired by the "broker" even in Massachusetts. Gifford v. Eastman, 251 Mass. 520, 146 N. E. 773 (1925). Even though the contract is one of sale, after the dealer has appropriated certificates to the contract he holds them as pledgee [Schofield v. Jackson, 99 Conn. 515, 122 Atl. 98 (1923)] or, as stated by some courts, as bailee [see In re Banker's Capital Corp., 51 F. (2d) 737 (S. D. N. Y. 1931)] subject to a lien for the purchase price.

32. In re Banker's Capital Corp., supra note 31 . 
in the absence of definite allocation to the sales contracts. ${ }^{33}$ If, however, the "broker" was acting as agent, specific allocation of the stock to orders is not necessary, the customers of that class sharing as tenants in common under the pledgor-pledgee relationship. ${ }^{34}$

Analogous problems are raised where the dealer, with money advanced by the customer, purchases stock pursuant to the customer's order and pledges the stock for a personal loan. The mere acquisition of the stock by the dealer has been held insufficient to appropriate the particular stock to the customer so as to vest title in him.3.5 Moreover, if the "broker" is acting as a dealer or vendor and the contract of sale does not provide otherwise, he must deliver or tender delivery to the customer. But where he is acting as agent no such tender is necessary, the customer's only defense being a counterclaim for any damages suffered. ${ }^{36}$ In case he was selling stock to the customer in the manner of a merchant, the delay in the delivery or tender of the certificates might be fatal. The general principle is that when no time for performance is set, the duty is to perform within a reasonable time. ${ }^{37}$ Or when the contract contemplated delivery in a specified time, failure to deliver by that time bars an action for the price. ${ }^{38}$

33. In re Banker's Capital Corp., supra note 31 , on analogy to rules governing contracts for sale of other personalty. Marshall v. Roettinger, 294 Fed. 158 (C. C. A. 6th, 1923). Cf. Wills v. Investors Bankstocks Corp., supra note 25.

34. Duel v. Hollins, 241 U. S. 523 (1916); Skiff v. Stoddard; Le Marchant v. Moore, both supra note 31 .

35. Coolidge v. Old Colony Trust Co., 259 Mass. 515, 156 N. E. 701 (1927).

On the lien of a vendor (dealer) as compared with the lien of a pledgee, see Leahy v. Lobdell, Farwell \& Co., 80 Fed. 665 (C. C. A. 6th, 1897); Markham v. Jaudon, supra note 31. Where the contract is one of sale the dealer is not liable in conversion for disposition of the stock where, as in case of an instalment sale, title had not passed to the customer. Sackville v. Wimer, 76 Colo. 519, 233 Pac. 152 (1925); Maw v. Fay, 248 Mass. 426, 143 N. E. 315 (1924).

Cf. The liability for conversion of a "broker" who acts as agent. Mayer v. Monzo, 221 N. Y. 442, 117 N. E. 948 (1917) ; Content v. Banner, 184 N. Y. 121, 76 N. E. 913 (1906); MEYer, op. cit. supra note 31, § 136. An analogy is the customer's action for conversion on a wrongful repledge. Douglas v. Carpenter, 17 App. Div. 329, 45 N. Y. Supp. 219 (1st Dep't 1897); In re Salmon Weed \& Co., Inc., 53 F. (2d) 335 (C. C. A. 2d, 1931).

36. Community National Corp. v. Kahle, 233 App. Div. 334, 252 N. Y. Supp. So 4 (4th Dep't 1931).

37. Orr v. Keith, supra note 25 , the court saying at $39,139 \mathrm{~N}$. E. at 510 : "If the contract was to sell and deliver property so fluctuating in value as shares of stock, the period of six months from July, 1921, to the beginning of the year 1922 was an unreasonable time for performance ..." See Union Corp. Ltd. v. Charrington, 19 T. L. R. 129 (1902). "Although what is a reasonable time is ordinarily a question of fact, it may be dealt with by the court as a question of law, when there is no room for dispute." Orr v. Keith, supra.

38. Heimerdinger v. Schnitzler, 231 App. Div. 649, 248 N. Y. Supp. 597 (1st Dep't 1931). 
Some jurisdictions, including New York, have held that where the "broker" acts as agent the customer cannot rescind the transaction against him, the action of rescission lying only against the seller. ${ }^{39}$ Consistently therewith it has been held that the only remedy by the customer against the "broker" would be for damages caused by the delay. ${ }^{40}$ Yet since he was acting in the capacity of an agent, the "broker's" obligation (arising from the bilateral contract between him and the customer) is limited to the use of reasonable care and diligence in filling the order and obtaining the delivery of the certificates. ${ }^{41}$ Hence if he can show that the belated delivery was due to no negligence of his, but to the delay of the transfer agent, the customer is not excused from performance. ${ }^{42}$ In case he was acting as dealer, however, in order to maintain an action he would need tender delivery to the customer within the time stated or within a reasonable time, the negligence or delay of a transfer agent being no excuse for his belated performance. ${ }^{43}$

Enough has been said to indicate that there are substantial reasons why a stock "broker" who acts a's a dealer would prefer to have a court or jury find that he acted as agent. The reasons for the preference in the Howell case might well have been the following. There was a delay in delivery of about three months. ${ }^{44}$ Although the jury found that this delay was not due to the negligence of plaintiff, ${ }^{45}$ yet if plaintiff had sued

39. Connelly v. Glenny, 233 App. Div. 198, 251 N. Y. Supp. 288 (4th Dep't 1931); Lund v. Keeler, 203 Wis. 458, 233 N. W. 769 (1931). For review of authorities see Bates and Douglas, supra note 4, at 994 et seq.

40. Lund v. Keeler, supra note 39. Others have held, however, that if the "broker" acting as agent fails to deliver within a reasonable time, the customer is not liable for refusing to accept delivery. Goldsmith, Myer \& Lobdell, Inc. v. Adler, 108 N. J. L. 312, 156 Atl. 642 (1931) (This case involved, however, an order for stock of United Founders as in the Howell case. Whether the broker was acting as a dealer does not appear. Nor are inferences permissible from the opinion); Howe, Snow, Corrigan \& Bertles v. Vander Veen, 223 Mich. 572, 194 N. W. 508 (1923) (broker bought after customer countermanded). See cases collected in Note (1932) 77 A. L. R. 308. The terms of the contract between customer and "broker" as to method of execution of the order and tender to the customer are controlling. Drake-Jones Co. v. Drogseth, 246 N. W. 664 (Minn. 1933).

41. Bates and Douglas, supra note 4, at 964 et seq.

42. Eddy v. Schiebel, 112 Conn. 248, 152 Atl. 66 (1930), holding the broker not liable for the delay of the transfer agent in transferring the shares to the customer where the broker himself was not negligent.

43. See cases supra notes 37,38 . An agent-customer relationship as contrasted to a dealer-customer relationship would not permit the customer to repudiate the order after execution by the "broker" so as to be relieved from liability to the "broker" for the price. See Lloyd v. Silvers, 274 S. W. 253 (Tex. Civ. App. 1925); Matousek v. Bank of Europe Trust Co., 234 App. Div. 328, 255 N. Y. Supp. 150 (1st Dep't 1932).

44. Defendants' order was placed with plaintiff Sept. 11, 1929. Record, 22 et seq. Delivery was tendered at defendants' bank with draft attached Dec. 10, 1929. Defendants refused payment. Record, 68, 69.

45. The trial court charged that "plaintiff was not responsible ... if it acted as broker for any delay in the delivery of this stock unless that delay was due to some want of 
as dealer (or vendor) it seems likely that this delay would have been fatal. $^{46}$ Furthermore, in an action as dealer for the price, plaintiff would have been confronted with the defense that defendants repudiated prior to appropriation of shares to the contract. ${ }^{47}$

There are, to be sure, risks in suing as agent not inherent in a suit as dealer. Thus an agent who sells his "own" stock to his principal (the customer) without full disclosure may not enforce the contract against the principal. Or, in the case of executed transactions, he may be liable to the customer in rescission, even though the price was fair and the bargain as good or better than could have been obtained elsewhere. ${ }^{48}$ As stated by the New York Court of Appeals in Taussig v. Hart: ${ }^{10}$

". . . the law does not permit an agent employed to purchase, to buy of himself. It is no answer that the intention was honest and that the brokers did better for their principal by selling him their own stock than they could have done by going into the open market. The rule is inflexible, and although its violation in the particular case caused no damage to the principal, he cannot be compelled to adopt the purchase."

Since the plaintiff in the Howell case sued as agent of the customer, it would seem that he brought himself within this rule. But without mentioning the Taussig case or discussing the point, the Court of Appeals held otherwise. Previous, however, to the Howell suit, the court had decided the case of Kinney $v$. Glenny. ${ }^{50}$ In that case a customer sued his "brokers" to rescind an agreement for the purchase of shares of stock, claiming that they had acted as his agents. A regular brokerage commission had been charged the customer, and while the confirmation slip read "sale to you," the customer had had no actual knowledge that anything other than a normal "brokerage" transaction was involved.

care on its part ..." Record, 119. One bit of evidence that plaintifi was negligent (even assuming it was acting as agent) was not emphasized by the defense. It appeared (Record, 74-78) that plaintiff lumped defendants' order with those of other customers and did not request the transfer agent to send a certificate in the denomination of 25 shares to fill the defendants' order. Consequently the transfer agent returned certificates of larger denominations which had to be returned to be broken down.

46. See cases supra notes 37,38 .

47. Defendants testified they repudiated Oct. 15, 1929. Record, 86, 87. This was in dispute. Record, 100, 101. Counterbalancing this matter, it appeared from plaintiff's evidence that defendants exercised their rights on the stock purchased and thus ratified the transaction. Record, 90 et seq. Defendants disclaimed this fact. Record, 93, 94. This controverted issue of fact was not submitted to the jury. By suing as agent plaintiff avoided the uncertainty of a jury on these two points. See cases supra note 43.

48. See Bates and Douglas, supra note 4, at 964 et seq., for an extended review of the cases.

49. 58 N. Y. 425,428 (1874).

50. 257 N. Y. 560,178 N. E. 795 (1931), af'g 231 App. Div. 311, 247 N. Y. Supp. 119 (1st Dep't 1931). The case is discussed in Bates and Douglas, supra note 4. 
But measured by the established standards of the security business, the "brokers" had in fact acted as dealers. Upon the understanding that they would pay the difference if the shares came back on the open market within sixty days, they had acquired the securities from a New York house at a price less than that charged the customer. The customer held the shares more than sixty days and on discovering the facts brought his action. The court, refusing to conclude that the defendants had sold plaintiff their "own" shares, dismissed the suit on the ground that plaintiff's only remedy against defendants was an action to recover the undisclosed profits. Thus a dealer who does not carry an inventory, who leads his customer to believe that he is acting as an agent and who in fact obtains an agent's commission in addition to his dealer's profit, may protect himself against rescission by defending on the ground that he acted as agent. By virtue of his non-disclosure he receives protection normally not accorded fiduciaries.

So it may be that the absence of an inventory in the Howell case is the differentiating factor between that case and Taussig v. Hart. But the reasons for drawing such a distinction are by no means obvious. To be sure, in the latter case the agent at the time of sale "owned" the stock in the sense that he had possession of the certificates for which he had paid the price. In the Howell case plaintiff was not carrying this stock in its portfolio. But it had an arrangement with Founders General whereby it agreed to distribute the stock. What the details of that arrangement were does not appear. ${ }^{51}$ If it definitely committed plaintiff to take a specified quantity of shares, the case is scarcely different from the Taussig case. If plaintiff merely had an option to acquire the shares, the difference would not be basic; nor would it be even though Founders General were under no duty to plaintiff to deliver any shares. The feature common to all those situations is the existence on the "broker's" part of an interest adverse to that of his customer, ${ }^{52}$ and inconsistent

51. Plaintiff's witness, Walter S. Wiggin, Re-Cross, Record, 57.

Q. Isn't it a fact ... that you had a private arrangement with the Founders General Corporation for assisting them in distributing the United Founders stock? A. We did have.

Q. And that in connection with that arrangement they would allot to you or protect you to enable you to make sales of that stock at a price that would not fluctuate to such an extent that you would not have protection on the fixed value, isn't that the fact? A. They would advise us of the market opening price of the day. We were to bill at that market price. No excess of it. And during the day if there was any change of price they notified us by wire or 'phone.

Q. That is, you started in each day with a quotation from them as to the price at which you could sell United Founders that particular day out of the stock they were going to distribute. A. At that market price in Boston.

52. See extended analysis of this point in Bates and Douglas, supra note 4. As stated in F. C. Adams, Inc. v. Frank H. Thayer \& a. Ex'rs., supra note 21, where the dealer was acquiring stock from outside sources, not selling from his inventory: "It was no 
with the fiduciary-agency relationship in which he claims to have acted. His dominant motive is profit to himself realized by buying as low as possible and selling to his customer as high as possible. Certainly no rational distinction can be drawn between a merchant who carries an inventory and one who does not. Retail and wholesale merchants in other lines frequently have insufficient merchandise on hand to fill orders of customers. Yet when they buy a supply sufficient to fill the orders they do not thereby act as agents for their customers. Thus in the Howell case although the plaintiff, who asserted rights of an agent, did not carry an inventory, he acted as a merchant and should be limited by the same rules as the plaintiff in Taussig v. Hart.

In such event the only factor which would protect him in his action would be full disclosure that he was acting as dealer or merchant. From the testimony of defendants it seems clear that full disclosure was made. ${ }^{53}$ To be sure, the profit plaintiff hoped to make in the transaction was not disclosed. ${ }^{54}$ But it would be the exception, not the rule, for vendors to disclose to their vendees the exact profit which they expected to realize. If a "broker" revealed that he was acting as dealer, that should suffice. But the Court of Appeals after accepting the verdict that plaintiff acted as agent concluded that deduction of plaintiff's profit of $13 / 8$ per cent was proper. It said: ${ }^{55}$

"Due to plaintiff's undisclosed relationship with the owner of the stock, nothing except the actual purchase price of the stock can be recovered from defendants. No profit or commission can be allowed."

As authority for this proposition the court cited Kinney v. Glenny. ${ }^{50}$ Thus the Howell case also assumes paradoxical aspects. A jury is allowed to find that a "broker," who by all standards of the business acted as dealer, acted as agent. Having been classified as agent, the

part of the order that the broker should make effort to obtain a better price. . . . If the plaintiff [dealer] obtained the stock, it did not concern the decedent how much it paid for it. . . The situation thus differed from the ordinary case in which it is the broker's duty to buy for the customer and to obtain the stock as cheaply as possible and not above such limit of price as the customer may set. . . . The plaintiff acted for itself and not for the decedent. Having an offer for the stock, it could make a profit if it could obtain the stock at a price below the offer, and this it sought to do." $85 \mathrm{~N}$. H. at 181-182, 155 Atl. at 690 .

53. See note 18 , supra.

54. Record, note 18, p. 59. Plaintiff's witness, Walter S. Wiggin, Re-Cross.

Q. You never told your customers what concession you were getting, did you? A. Why should we? They bought at the same price they could buy in the open market and they could have sold at the same price they bought.

Q. In any event you did not tell the customers your concessions or whatever benefit you were deriving out of the transaction on your sales of the United Founders, did you? A. We did not.

55. Supra note 1 , at 253,183 N. E. at 379.

56. Supra note 50 . 
"broker" is in the first place allowed to assert rights on a contract even though he had an interest adverse to that of his customer which, according to the court, he did not disclose. In the second place, having been found to be an agent the "broker" is deprived of his profit though in fact he was a dealer and the customer admitted that he knew he was so acting. And in the third place, by being classified as agent contrary to fact he avoids being put to the defense which a dealer normally must sustain.

The result of the Howell and Kinney cases may be either or both of the following legal propositions:

(1) A "broker" who by all standards of the security business is a dealer may nevertheless on the one hand assert rights or claim defenses peculiar to an agent provided he does not carry an inventory and, on the other, avoid the rule which forbids an agent to sell his "own" 57 stock even though he solicits orders for particular securities and fills them in the manner of a security merchant without an inventory.

(2) The question of whether or not a "broker" acted as agent or dealer is a question of fact.

In addition the Howell case may mean that even though the customer is not misled by the nature of the transaction, if a jury calls a dealer an agent he is deprived of his profit. The two cases have come perilously close to establishing as a matter of law the first proposition stated above. The reasons for the position of the New York courts on that proposition may well be due to a failure to treat the second proposition in a discriminating manner.

\section{III}

It is undoubtedly true that in one sense the question of whether or not a "broker" acted as agent or dealer is a question of fact. What the "broker" did may be controverted or in dispute. The determination of that question certainly is for the jury. But after it is ascertained what the "broker" did-his representations to the customer, the type of confirmation used, where and how he obtained the securities, who paid his commission-the legal consequences should remain for the court. Or to put it another way, if the issue is sent to the jury, it should be submitted under precise instructions as to what specific earmarks will constitute a "broker" a dealer on the one hand or an agent on the other.

The law is replete with analogies. Thus in a case involving the liability of the defendant to creditors on the ground that he was a

57. See Bates and Douglas, supra note 4. The coure in the Kinney case, after holding that the dealer was not liable, indicated that if any one was liable it was the seller from whom the dealer received the stock. Accordingly plaintiff sued Lisman \& Co. The complaint was dismissed. Kinney v. Lisman, 147 Misc. 431, 263 N. Y. Supp. 828 (Sup. Ct. 1933). 
partner in the business, the jury is allowed to ascertain what were the terms of his contract with his alleged co-partners. ${ }^{58}$ But as has been stated, "whether a partnership existed or not is an inference of law from the established facts ..." 59 If "the extrinsic facts and the inferences to be drawn therefrom are free from dispute" the question of construction is "exclusively a question for the court." в0

Similarly, in cases where the injury to plaintiff has been caused by one whom defendant calls an independent contractor but whom plaintiff calls a servant or agent of defendant, the appellate courts have worked out formulae defining in general these concepts. The distribution of powers between the court and the jury is well stated by the New York Court of Appeals: ${ }^{61}$

"As here, the answer may depend on a written contract. In the absence of technical phrases whose meaning is obscure, or of latent ambiguities making the subject-matter of the contract doubtful, the court must construe it. (Brady v. Cassidy, 104 N. Y. 147.) Again there may be an express oral contract. This too the court should construe. Or the existence of an oral contract may be denied, or its terms disputed. If so it is for the jury to pass upon its existence and provisions and under proper instruction to give effect to it. (Patten v. Pancoast, 109 N. Y. 625.) Or the contract, oral or written, may be ambiguous. Its construction may depend upon the intent of the parties in turn dependent on disputed facts. Then it becomes the duty of the jury again under proper instructions to determine this intent. Or there may be no express contract. One is to be implied from contradictory or disputed circumstances. Once more the jury must decide what was the actual relationship."

The instructions in the Howell case satisfied only in a formal way the tests of a dealer or agent relationship. The relevant portions of the charge were: ${ }^{62}$

"The plaintiff claims that as a result of that conversation [between Kellogg and Weinberg] it received an order to purchase 25 shares of this stock. The defendants claim as a result of that conversation that the plaintiff sold them 25 shares of this stock.

"That presents, gentlemen of the jury, a question of fact for you to determine. Of course, you are not limited solely to that conversation in determining whether or not this was a mere sale or whether brokerage services were involved, but you have a right to take into consideration all other testimony,

58. See Rider v. Hammell, 63 Kan. 733, 66 Pac. 1026 (1901); James Bailey Co. v. Darling, 119 Me. 326, 111 Atl. 410 (1920); T. R. Foley Co. v. McKinley, 114 Minn. 271, 131 N. W. 316 (1911) ; Eastman v. Clark, 53 N. H. 276 (1872); Mill Factors Corp. v. Margolies, 210 App. Div. 739, 206 N. Y. Supp. 434 (1st Dep't 1924).

59. James Bailey Co. v. Darling, supra note 58, at 328, 111 Atl. at 411.

60. T. R. Foley Co. v. McKinley, supra note 58, at 274, 131 N. W. at 318 .

61. Braxton v. Mendelson, 233 N. Y. 122, 124, 135 N. E. 198, ibid. (1922).

62. Record, 115-116. 
both oral and written, which you accept as credible and which bears upon that proposition.

"A broker, to define the term in very simple language, is an agent employed to purchase or sell for another. ...

"Now, you have the definition of a broker, you have the testimony of Kellogg, you have the testimony of Maurice Weinberg, you have the other details, both oral and written, which have been given in evidence with relation to this transaction. Determine, gentlemen of the jury, from that testimony whether this transaction was a sale, or whether it involved the brokerage services of the plaintiff. If you find that it was a sale, that is, if the plaintiff was not purchasing something for the defendant, but was selling them stock as the agent of another concern, then your verdict must be one of no cause of action ... That is the primary proposition involved. Determine that first. Was the plaintiff a broker in this transaction, or was he simply the agent of the owner of this stock?"

Certainly, this charge does not reveal even the gross differences in fact between a stock "broker" acting as agent on the one hand and as dealer on the other. It seems unlikely that the jury would supply the discrimination which the trial court failed to furnish. The distinctions which the court states as respects agency and sale, buried as they are in a long charge, would tend to blur rather than differentiate the two relationships. It is difficult to believe other than that a jury under such a charge would be likely to classify as an agent any dealer who was authorized by a customer to place an order for purchase, and who in a popular sense rendered "brokerage services" to the customer.

The distinctions between dealer and agent have been only generally articulated by the courts. ${ }^{63}$ Nevertheless, recent cases have recognized more and more the distinguishing characteristics of these two relationships. The New York Court of Appeals has on occasion adverted to them. ${ }^{64}$ Judge Merrill has well stated them as follows:

"Ordinarily stockbrokers are agents working for a commission. They attend to the purchase and sale of stocks or shares or other securities for and on behalf of clients. They are employed to buy and sell shares of stock of incorporated companies by their principals. It cannot be said that a person who buys for himself and sells to another is acting as a stockbroker for that other. Stockbrokers, on the other hand, do not transact business for themselves, but for others. Their employment is to buy or sell stocks, and they receive compensation for their services. They act as agents of the persons for whom the purchases or sales are made. Their interest in the transaction is only to the extent of the commission which they are to receive. On the other hand, stock dealers or jobbers are those who deal in stocks or shares. They

63. MEYER, op. cit. supra note 31,1932 Supp. $\S 43 a$.

64. See Wills v. Investors Bankstocks Corp., supra note 25; Markam v. Jaudon, supra note 31 . 
are persons who purchase or sell stocks, bonds or other securities on their own account. The distinction between a stockbroker and a stock dealer is clear and well defined. Having in mind the distinctive features between stockbrokers and stock dealers or jobbers, the record on this appeal shows that Schofield \& Co. were actually acting as dealers and not as brokers in relation to the two transactions. In the first place, Schofield \& Co.'s letterhead represented them to be specialists in 'investment securities.' Secondly, the written confirmation of sale from Schofield \& Co. to plaintiff read: 'We are pleased to confirm sale to you.' It did not read: 'We have this day sold or purchased for your account and risk,' which would have been the natural wording of the confirmation had Schofield \& Co. been acting as the brokers for plaintiff. Furthermore, the evidence shows that Schofield \& Co. bought the ten shares of the Equitable Trust Company stock from defendant at ninety-two dollars per share, and on the same day sold the same stock to plaintiff at ninety-five dollars per share; and that Schofield \& Co. purchased of defendant twenty shares of the Aetna Life stock at ninety-nine dollars a share, and the same day sold the same stock to the plaintiff at one hundred and one dollars and fifty cents a share. Nothing, it seems to me, could more clearly indicate the capacity in which Schofield \& Co. were acting, and that they were at the time, not the agents of plaintiff, but were dealers in the securities which they sold to him. There is no claim on the part of plaintiff that Schofield \& Co. were to receive any commissions whatever. Their compensation was in the increased price which they received from plaintiff for the two blocks of stock in question. The form of confirmation used by Schofield \& Co., showing a profit to it of three points on one stock and two and one-half points on the other, shows the true relationship between said company and plaintiff." ${ }^{65}$

Other courts have recognized the same distinctions and in 'general have employed the following differentiating characteristics or earmarks to distinguish the dealer from the agent.

(1) The form of the confirmation "sold to you" rather than "bought for your account" is evidentiary of a dealer-customer relationship. "ib

(2) The fact that the customer is not charged any commission is likewise evidence that the "broker" acted as dealer. ${ }^{67}$

65. Wills v. Investors Bankstocks Corp., 232 App. Div. 197, 202-203, 249 N. Y. Supp. 705, 711-712 (1st Dep't 1931) (dissenting opinion), rev'd, 257 N. Y. 451, 178 N. E. 755 (1931).

66. Farr v. Fratus, supra note 21; Hornblower v. James, 155 Atl. 568 (R. I. 1931); McNulty v. Whitney, 273 Mass. 494, 174 N. E. 121 (1930); Williams v. Bolling, 138 Va. 244, 121 S. E. 270 (1923). See MEYER, op. cit. suppra note 31, 1932 Supp. § 43a. But the receipt by the customer of a dealer's confirmation slip is not by itself notice to the customer that the "broker" was acting as dealer. McNulty v. Whitney; Williams v. Bolling, both supra. And see discussion in Bates and Douglas, supra note 4, at 985 et seq.

67. Trowbridge v. O'Neill, 243 Mich. 84,219 N. W. 681 (1928); F. C. Adams, Inc. v. Frank H. Thayer \& a. Ex'rs., supra note 21. See Meyer, op. cit. supra note 31, 1932 Supp. § 43a. 
(3) The "broker" when acting as dealer usually acquires the stock at one price and transfers it to the customer at another. ${ }^{68}$

(4) If the "broker" is selling from his inventory he is acting as a dealer. ${ }^{69}$

(5) $\mathrm{He}$ is nonetheless a dealer even though he had no inventory but was acquiring securities for his customer from any of several sources in the manner of any merchant." For a "broker" to sell from his own inventory would establish that he acted as a dealer; but it is not true, conversely, that the absence of an inventory makes him an agent. That alone would not discriminate between an agent and a dealer, though it would be evidence to be weighed along with other of the criteria mentioned.

A "broker," however, need not have all the foregoing characteristics in order to be a dealer. For example, in the Kinney case the "broker" took commissions from both parties. Nor does it mean that those characteristics are the only ones differentiating a dealer from an agent. Thus in the Kinney case the "broker" guaranteed to the seller that the stock would not come back onto the market within sixty days, a contract consistent only with a dealer relationship.

As stated above, it was clearly established in the Howell case that

68. State v. Schofield, 114 Conn. 456, 463, 159 Atl. 285, 288 (1932); F. C. Adams, Inc. v. Frank H. Thayer \& a. Ex'rs., supra note 21. See MEYER, op. cit. supra note 31, 1932 Supp. $\$ 43 a$; Gast v. Buckley, 23 Ky. L. 992, 64 S. W. 632 (1901); State v. Debenture Guarantee \& Loan Co., Ltd., 51 La. Ann. 1874, 1887 (1899).

69. McNulty v. Whitney, supra note 66 , and cases cited and discussed in Bates and Douglas, supra note 4. See Cohen v. Paine, Webber \& Co., supra note 22.

70. Coolidge v. Old Colony Trust Co., supra note 35. ("If one of his customers wanted one of the real estate stocks in which Burroughs specialized, he quoted a price. . . When his customer accepted the price quoted, Burroughs then went into the market and bought the stock as cheap as he could and kept the difference."); State v. Schofield, supra note 68 (defendant-"broker" was a member of a distributing group somewhat comparable to plaintiff in the Howell case and was beld to be acting as a dealer and not as an agent); F. C. Adams, Inc. v. Frank H. Thayer \& a. Ex'rs.; Farr v. Fratus, both supra note 21; Agar v. Orda, supra note 30. And see Schofield v. Jackson, supra note 31 ("broker" was under contract with the issuing corporation "to market an entire new issue" of stock).

Some transactions between dealer and customer may initially be nothing but an offer on the part of the customer to buy from the dealer at a price named. For example, in F. C. Adams, Inc. v. Frank H. Thayer \& a. Ex'rs., supra note 21 , at $181-2,155$ Atl. at 690 , the court said: "So far as appears, the plaintiff had no duty to obtain any stock at a price it did not choose to pay. In substance, an offer was made to buy which the plaintiff accepted when it thought it to be for its interest to do so. The situation thus differed from the ordinary case in which it is the broker's duty to buy for the customer and to obtain the stock as cheaply as possible and not above such limit of price as the customer may set."

Of course the fact that the "broker" acting as agent assumed the position of principal towards the buyers or sellers with whom he dealt does not make him a vendor or dealer as respects his customer. American Cotton Mills v. Monier, 61 F. (2d) 852 (C. C. A. 4 th, 1932); Bates and Douglas, supra note 4. 
plaintiff (1) was the local representative of a wholesaling house; (2) sold the stock at as nearly a fixed price as would be possible in case of stocks; (3) confirmed the transaction with a "sold to you" slip; (4) ordered the stock from the wholesaler without advance payment or any "margin" from defendants; (5) solicited the order for this particular stock; (6) was bound by the prices and rules of the wholesaling house; (7) charged defendants no commission; (8) made no disclosure to the defendants of its profit; (9) received a dealer's discount from the wholesaling house; and (10) did not call for payment until the stock was tendered to defendants. Those facts being established beyond doubt and defendants admitting they knew plaintiff acted as dealer, it would seem that the correct procedure would have been to grant the motion for non-suit. But if the case were going to the jury, it should have been sent merely for the purpose of finding whether or not the evidence supported the foregoing facts. Once those facts were established then the question of whether or not plaintiff was dealer or agent became a question of law for the court. As a question of law it is clear that plaintiff was a dealer.

From the viewpoint of procedure and trial court strategy the Howell case appears to have the following significance. Defendants stood on their motion for non-suit and did not except to the charge or submit requests to charge describing in more detail the differentiating characteristics of dealer and agent. Until counsel sharply differentiate the legal and factual distinctions between dealer and agent, it may confidently be expected that trial and appellate courts will continue to treat these concepts in a blurred fashion. 